\title{
6 \\ A COMMON CURRENCY FOR THE PACIFIC ISLAND ECONOMIES?
}

\author{
Ron Duncan
}

The question I examine here is whether the Pacific island countries-or at least a substantial number of them-should adopt a common currency (or currency union) as part of a process of regional integration. There are also related questions such as which currency they should adopt and when should they do so. The regional integration may only be between the Pacific states, or it may be with other countries. At present the only other countries under consideration for regional integration with the Pacific are Australia and New Zealand, but regional integration could potentially involve other countries in the Asia Pacific region. Choice of a common currency could involve the adoption of a 'Pacific dollar' - especially if the regional integration is only among the Pacific nations - or it could imply the adoption of one of the other non-Pacific currencies already being used by some of the Pacific countries-that is, the Australian, New Zealand, or US dollars.

Prior to the report by the Australian Senate Foreign Affairs and Trade Committee (Commonwealth of Australia 2003) recommending the consideration of a Pacific Economic and Political Community-including the adoption of a common currency — and the Forum Leaders' Pacific Plan for the investigation of further regional cooperation, there had been some discussion of the adoption of a common currency among the Pacific island countries and Australia and New Zealand (Duncan 1994, 2002; Duncan and Xu 2000; de Brouwer 2000; Hughes 2003 and Jayaraman 2003). Since the Senate Committee report, further discussion of the idea has ensued, mostly negative 
(Chand 2003; Bowman 2004; Jayaraman 2005; Jayaraman et al. 2005 and Mawuli 2005). There has been little reaction from the Pacific to the proposal for a common currency, but what has emerged has also been mostly negative. As a long-time supporter of the idea of formal economic integration between those Pacific island countries that wish to do so and Australia and New Zealand (Duncan 1994) - including adoption of the Australian dollar as the common currency-I am happy to have this opportunity to re-examine the arguments for and against a common currency for the Pacific states. I believe that the case for adoption of the Australian dollar set out in de Brouwer (2000) and Duncan and $\mathrm{Xu}(2000)$ still holds, so I will mainly examine the subsequent arguments against the proposal.

The primary consideration for Pacific states in deciding whether to adopt a common currency and which currency to adopt is whether they form an 'optimal currency area'. However, there are also political economy and other considerations to take into account. Are the Pacific island nations themselves an optimal currency area, or do the Pacific nations and Australia and New Zealand-or the Pacific and any other possible regional partner(s) - satisfy the conditions necessary to form an optimal currency area? Or could changed conditions in the future mean that they would form an optimal currency area? These are questions that ultimately depend for answers on empirical analysis and much of the necessary analysis has not been carried out. Therefore, I will only offer arguments to support the claim that optimal currency area considerations are paramount and discuss some related issues, while examining the recent counter-arguments.

\section{OPTIMAL CURRENCY AREA THEORY}

In putting forward the theory of optimal currency areas, Mundell (1961) was concerned about the relationship within a country between the exchange rate and the economic conditions of different regions in that country. As he said,

If labor and capital are insufficiently mobile within a country then flexibility of the external price of the national currency cannot be expected to perform the stabilisation function attributed to it, and one could expect varying rates of unemployment or inflation in the different regions (Mundell 1961:664).

To illustrate Mundell's point, consider the case of Tasmania. If there is an external shock—such as a commodity price decline-that adversely affects industries in Tasmania, labour and capital can freely move out of Tasmania and 
into the rest of Australia. But if labour and capital could not move in this way, there would have to be different prices for labour and capital in Tasmania than in the rest of Australia, or Tasmania would have different rates of unemployment or inflation. If Tasmania could not have different prices for capital and labour than the rest of Australia and if Tasmanian labour and capital could not move freely to other parts of Australia, then it would be desirable for Tasmania to have a different exchange rate from the rest of Australia. However, labour and capital can move freely between Tasmania and the rest of Australia and there can also be some differentiation in the prices of labour and capital. Tasmania can therefore have the same exchange rate as the rest of Australia.

To put it another way: in order for Tasmania to have the same exchange rate as the rest of Australia, it must experience the same external shocks as the rest of Australia; or if it experiences asymmetric shocks, it must either have freedom of movement for its labour and capital or have flexibility in differentiating the prices of its labour and capital. However, while the price of capital is flexible throughout Australia, we have to acknowledge that the price of labour is not flexible, especially in a downward direction, and regional differentiation of wages is limited. Therefore, there is greater importance on the freedom of movement of labour - which in this case is uninhibited, except for the costs of adjustment. The costs of adjustment of labour and limits on the scope for regional differentiation of wages — offset to some degree by inter-state transferscould be seen as explaining any differences in rates of unemployment between regions within Australia.

The same logic applies to adoption of the Australian dollar by Pacific nations. For the Australian dollar to be an appropriate exchange rate regime, the Pacific must experience the same external shocks as Australia, or they must have independence in changing the prices of their labour and capital, or capital and labour must be able to migrate freely; or, alternatively, each of these three conditions must exist to a sufficient extent to provide the necessary basis for an optimal currency area. As well, there may be inter-state transfers to help compensate for any disequilibrium. De Brouwer (2000) has broadly discussed the extent to which each of these conditions applies and recognised that optimal currency area conditions may be satisfied by any one condition being fully satisfied or by two or more being satisfied to some extent. Here, I extend his arguments by exploring in more detail the extent to which the optimal currency area conditions are satisfied or need to be satisfied, or could be more satisfied in future. 
First, it is important to distinguish between two sets of countries: the very small countries that already use the Australian or New Zealand dollar and those with their own currencies (I ignore the Pacific countries that use the US dollar, as the likelihood of their adopting the Australian dollar in the near term is not high). Kiribati, Nauru and Tuvalu are micro-states that use the Australian dollar, while Cook Islands, Niue and Tokelau are small countries that use the NZ dollar. Of most relevance to this discussion is that there is little in the way of private sector activity in these Pacific countries. Therefore, external shocks, the mobility of labour and capital, and the flexibility of their wages matter little as normal market adjustments to external shocks play a very minor role in their economies. Until circumstances change in these small countries with very limited private sectors, it appears that they have made the right choice by using the currency of a much larger country with sound monetary and fiscal policy and with which they have extensive trading relationships.

Hughes (2003) has argued that the similarly poor performances of the Pacific island nations using Australian or New Zealand currency and those with their own currency is an indication that it would not be advantageous for the other Pacific countries to give up their monetary independence. However, an argument about something so complex as economic growth on the basis of a single variable has limited use. The circumstances of the other larger Pacific states deserve more serious analysis with respect to their exchange rate regimes.

The countries of primary interest here are the countries that have their own currencies and central banks—namely Fiji, Papua New Guinea, Samoa, Solomon Islands, Tonga and Vanuatu. These are more substantial economies with larger private sectors - though unfortunately their private sectors are not as large as is desirable. In these cases, we have to consider not only whether a common currency would be a feasible alternative but also whether it would be desirable from the viewpoint of providing advantages in terms of fiscal and monetary management.

Empirical analysis of the extent to which these countries share common external shocks with each other or with Australia and/or New Zealand has not been carried out, except for the relationship between Papua New Guinea and Australia. Xu (1999) estimates the extent to which Papua New Guinea shares external shocks with its major trading partner, Australia. The results of Xu's econometric tests suggest that at least 75 per cent of the variation in industry 
output growth rates in the two countries can be attributed to industry-specific shocks common to both countries (such as international commodity prices), while 23 per cent is attributable to country-specific disturbances (such as domestic economic policy and natural disasters). Xu concludes that the results pointed to adoption of the Australian dollar or a currency board with the kina strongly fixed to the Australian dollar as the optimal exchange rate policy for Papua New Guinea.

It has been argued that the export baskets of the two countries are not the same and therefore movements in international commodity prices will not affect the two economies in the same way. However, as Duncan and Xu (2000) point out, there is substantial auto-correlation between international primary commodity prices (even though some of the markets appear to be unrelated), which can help to explain the high degree of commonality in the external shocks of the two countries. The Australian dollar is widely regarded as a primary commodity currency because of its co-movement with global primary commodity prices. The Papua New Guinea kina, which has been floating since 1994, can most likely be categorised similarly.

The economies of the other Pacific island countries with their own currencies-Fiji, Samoa, Solomon Islands, Tonga and Vanuatu-are also highly dependent upon primary commodities for exports. It is likely therefore that, similar to Papua New Guinea, their industry output has a high degree of commonality with Australia in terms of industry-specific shocks. This conclusion remains to be tested. However, if it is the case to a significant degree, the condition for an optimal currency area with Australia is satisfied and there is not so much need for the countries to have mobility of labour and capital or flexibility in prices of labour and capital. Asymmetry in industry-specific shocks and country-specific shocks may, however, still matter. Therefore, it is important to examine the extent of the flexibility in prices of labour and capital and the mobility of labour and capital.

Samoa and Tonga have had relatively easy emigration to New Zealand (and ultimately to Australia) for many years. In fact, despite still having quite high fertility rates, their emigration rate is so high that population growth in these two countries is close to zero. Investment in education in Samoa and Tonga is also relatively high, and can be interpreted as investment in the income risk diversification of households. Indeed, Tonga boasts more PhDs per head of population than any other country. 
Apart from the Indo-Fijian population of Fiji, labour from the other four Melanesian countries has had limited emigration possibilities. There has been a steady stream of 5,000-6,000 Indo-Fijian emigrants since the 1987 coups, cumulatively totalling around 100,000. Of these, about 10,000 have been skilled to highly skilled professionals such as doctors, lawyers, accountants, computer specialists and teachers. In recent years, however, the aging of the populations of the high-income countries has opened up the possibilities for offshore employment of Melanesians, particularly in 3D (dirty, difficult and dangerous) semi-skilled jobs. For example, there are around 3,000 Fijians in the British armed forces, around one-half that number are employed as security guards in Iraq and Kuwait, and, if one believes newspaper reports, an estimated 10,000 Fijian 'care givers' are employed in the United States. Thus, with the continuing aging of the global population, the mobility of skilled and semiskilled labour in these Melanesian countries-as well as in the other Pacific island countries-will only increase. This conclusion does not apply to the majority of the Melanesian population who are primarily poorly educated, rural dwellers. The recent interest in short-term work visas for Pacific peoples in Australia and New Zealand could lead to some employment opportunities for this category of workers, but it is hard to see such programs being large or growing very fast.

If labour mobility is poor for the large proportion of lower-skilled labour, how flexible are wages? As Forsyth (1998:86) notes

The majority of the PDMCs [Pacific Developing Member Countries] either have not set a statutory minimum wage or have a rate so low as to be clearly 'non-binding', i.e., below the market-clearing rate, or have a potentially binding rate but do not police or enforce it. The only countries in which minimum wage rates clearly lie above the market-clearing rates are Fiji and Papua New Guinea.

Fiji and Papua New Guinea are the only Pacific nations with strong unions. But even in these countries, minimum wage laws only affect the small proportion of the labour force that is in formal employment. Most of the labour force earn livelihoods as smallholder farmers, through forms of semi-subsistence agricultural and fishing pursuits, and through urban informal activity. Therefore, for these parts of the labour force, real wages are not 'sticky'. In fact, as seen in Papua New Guinea with the large depreciation of the kina and the increased inflation in recent years, many have suffered large declines in real incomes. Thus, it would appear that for the semi-skilled and skilled workers in the 
Pacific, labour mobility is quite high and increasing, while for low-skilled labour wages are flexible. While increased off-shore employment opportunities would be beneficial for the low-skilled labour force in these countries, they are not necessary for these countries to be an optimal currency area with Australia and New Zealand.

\section{ARGUMENTS AGAINST ADOPTING THE AUSTRALIAN DOLLAR}

Bowman (2004) criticises the idea of Pacific island countries adopting the Australian dollar on the basis of time series tests of the relationship between the independent currencies of Pacific states with the Australian dollar, the Japanese yen, the British pound and the US dollar, and a comparison of the trading relationships between Pacific nations and Australia and the Pacific nations and Asia. Bowman finds that, except for the Tongan pa'anga, the Pacific island countries' currencies are more highly correlated with the US dollar than with the Australian dollar. She also points out that the Pacific is beginning to trade less with Australia and more with Asian countries, and that these two findings argue against adopting the Australian dollar.

In this case, however, regression analysis of the relationship between the currencies is not an appropriate test for an optimal currency area. The exchange rates of the Fijian dollar, the Solomon Islands dollar, the Tongan pa'anga, and the Vanuatu vatu are fixed to individual baskets of currencies set by the central banks. The Papua New Guinea kina could best be described as a 'managed float'. Essentially, all that Bowman has done is estimate the weights of the currencies in the baskets of the adjustable currency pegs (which are not made public by the central banks). It is of interest to have these estimates, but they are not a test of the extent to which these Pacific countries and Australia share industry-specific shocks.

Moreover, with the Pacific island states and Australia being 'small countries' in trade terms, the extent to which they trade with each other is not as important as the extent to which they trade with other countries, and are therefore affected by changes in global conditions. That the Pacific may be moving away from trade with Australia to trade with Asian countries is not an argument against the Pacific being an optimal currency area with Australia. Australia's own trade has moved heavily towards Asia and this means that Pacific states and Australia will both experience the shocks coming from that trade link. 


\section{Pacific Island Regional Integration and Governance}

In his several publications arguing against the formation of a currency union between Pacific states and Australia and New Zealand, Jayaraman (2001, 2003, 2005, and Jayaraman et al. 2005) discusses various indicators that have been put forward in the optimal currency area literature as key deciding factors for a currency union-openness, intra-trade volume, degree of product diversification, similarity in industrial structures, correlation in economic activities, similarity in inflation rates, flexibility in wages and prices, and factor mobility. Further, Jayaraman (2001, 2003 and 2005) and Jayaraman et al. (2005) carry out tests on various indicators and find that the optimal currency area conditions are not satisfied. I find the tests undertaken and the arguments made unsatisfactory on several grounds.

Several of the conditions suggested as needing to be satisfied for the formation of an optimal currency are endogenous to regional integration that includes a common currency (as Jayaraman acknowledges). Others are of second-order importance to the primary conditions that I have discussed previously. Openness, intra-trade volume, output diversification, inflation rates, and factor mobility are all likely to change in Pacific states with closer economic integration with Australia and New Zealand. For example, forgoing monetary independence on adoption of the Australian dollar can be argued to be an important reason for Pacific nations to take this action, given the tendency of many towards high fiscal deficits with their adverse effects on inflation rates, interest rates, and exchange rates. Also, intra-trade volume can be expected to increase with use of a currency that reduces exchange rate risk and other transaction costs. Intra-trade volume, degree of product diversification, similarity in industrial structures, and high correlation in economic activities appear to be unimportant if the primary conditions for an optimal currency area are satisfied. The importance of country-specific risks could also be reduced with closer integration if, for example, it leads to reductions in political instability.

Jayaraman (2005) presents correlations of economic growth rates, inflation rates, interest rates, and exchange rates between Pacific countries and Australia and New Zealand as tests of an optimal currency area. Jayaraman et al. (2005) present time series regression results on convergence between the Pacific states and Australia and New Zealand in nominal exchange rates, real effective exchange rates, inflation rates, and real GDP growth rates. Tests of correlations or convergence in GDP growth rates appear to be beside the point in regards this issue. The nominal exchange rate is a mechanism for short-term, economywide adjustments to external shocks. What is of interest, therefore, is the 
coincidence of business cycles, not the rate of growth of the economies. As argued previously, the inflation rate should be a strongly endogenous variable to the formation of a currency union between these countries and therefore a comparison of inflation rates or measures of their convergence are not really of interest here. Also, as argued above, tests of correlations or convergence of nominal exchange rates are primarily reflecting the currency basket weights adopted by Pacific states. As de Brouwer (2000) points out, real effective exchange rates are endogenous within the country, reflecting the interaction of monetary and fiscal policies, and can therefore be expected to be endogenous to the formation of a currency union or adoption of a common currency.

Mawuli (2005:48) criticises Xu's (1999) conclusion that Australia and Papua New Guinea formed an optimal currency area on the grounds that his analysis ignored the

...dominant role that productivity plays in the determination of the foreign exchange rate of a currency and the dissimilarities of the two economies - the Australian economy is dominated by services, especially financial services, while the PNG economy is dominated by commodities together with a large base of subsistence production.

While the trends in exchange rates may be primarily influenced by productivity growth, it is the short-term reflection of external shocks that is of importance here. Also, dissimilarities in the structure of the economies, especially where these are largely in the form of non-tradables, is hardly relevant. As noted earlier, both the Australian and Papua New Guinean currencies are basically 'primary commodity' currencies because of the importance of primary commodities in their exports.

Mawuli (2005) also argues against adoption of the Australian dollar by Papua New Guinea by using the example that Liberia has used the US dollar for over a century and 'has experienced disastrous consequences-a persistent, broadly based depressed economy, which partly accounts for its political instability, civil war and social disintegration'. I fail to see how the use of the US dollar could be held responsible for these developments. Moreover, many examples could be found of countries using the US dollar that have been successful.

\section{POLITICAL ECONOMY AND OTHER ISSUES}

The political economy arguments over whether the Pacific should adopt a common currency have been well covered in the literature, so I will only discuss them briefly. Sovereignty is the first issue that comes to mind with many 
people. In the Pacific there is a perception that to move away from one's own currency means giving up part of one's sovereignty. As with any such issue, the decision should rest on the balance of the benefits and the costs. Countries in the European Union have been willing to adopt a common currency in the interests of closer political integration, with the ultimate aim of reducing the likelihood of future conflicts between them. In the case of the Pacific, the sense of a loss of sovereignty over giving up their own currency would seem to be far outweighed by the potential gains. These gains are largely in the form of encouragement of trade from reductions in transactions costs due to reducing the risks associated with their highly illiquid currencies: inflation rate risk, interest rate risk, and exchange rate risk.

Loss of monetary independence and thus the loss of a degree of freedom in economic management are also seen by some as negatives. But monetary independence has minuses as well as pluses. When I argued for Papua New Guinea and Solomon Islands to adopt the Australian dollar (Duncan and $\mathrm{Xu}$ 2000; Duncan 2002), my position was based on concern over the loss of central bank independence in these countries. While central bank independence has been bolstered in Papua New Guinea through legislation adopted since that time, and the international intervention in Solomon Islands has reduced the threats to central bank independence in that country, it would be taking an overly optimistic position to argue that central bank independence is now assured in these countries; or that it is assured in the other Pacific island countries with central banks. A point of major concern to me is that in small countries fiscal policy drives monetary policy. So, despite legislative protection, the threat of loss of monetary independence under future governments will continue. It should be remembered that legislative protection in Solomon Islands did not in the past prevent the government from central bank borrowing beyond its legislative limits.

An argument is also made that the central banks are one of the few institutions that have functioned relatively well in the Pacific. This is true. They have generally performed far better than most other government organisations. However, when fiscal policy dominates monetary policy, and when skilled people such as those employed in the central banks are in very short supply, it appears to be a misallocation of resources to have these people working in the central bank rather than in the treasuries or finance departments. The key question appears to be how to create conditions in treasuries, finance 
departments, and statistics offices that replicate the central banks' capacity to recruit and retain such skilled people.

An issue on which research is needed is the cost to small countries such as a Pacific country of running a central bank. It may be claimed that the profits from seigniorage (from printing currency) more than cover the cost of maintaining a central bank. However, if in the process of changing over to Australian currency there was an agreement for the Pacific state to hold a share of the Australian seigniorage (as I suspect would be possible), the seigniorage should not be included in the assessment of the benefits and costs of maintaining the existing central banks. My impression is that a central bank is a rather expensive luxury for small countries.

With respect to the debate over loss of monetary independence, I believe that some attention should be given to the issue of the 'trilemma' of macroeconomic policy. The policy 'trilemma' facing governments is that it is not possible simultaneously to peg the exchange rate, maintain an open capital market, and have monetary policy autonomy. Only two of these policy goals may be followed at the same time. For example, a government can follow the objectives of exchange rate stability and an open capital market by adopting a permanently fixed exchange rate, such as a common currency or a currency board arrangement, but in doing so it has to give up monetary independence. If it elects to have monetary independence and an open capital market, it can float the exchange rate but therefore cannot have exchange rate stability. Finally, if a government chooses the goals of exchange rate stability and monetary independence, it cannot have the goal of capital market integration.

Taylor and Obstfeld (2004) argue that what was known as the Bretton Woods system-currency pegs and capital controls as cornerstones—-was derived from suspicion of open capital flows due to the crises of the 1930s and association of floating exchange rates with speculation and instability. Therefore, the architects of the Bretton Woods system (John Maynard Keynes and Harry Dexter White) espoused capital controls and fixed exchange rates in order to prevent the disruption of trade. Taylor and Obstfeld argue that this view of the global economy - that the world could be kept safe for trade by constraining flows of private capital-proved to be an illusion. The global gains from expanded trade in the 1960s and 1970s and the necessity for large payments transactions put pressure on the balance of payments and led to frequent adjustments in currency pegs. Eventually the system collapsed and trade and 
capital flows have flourished, to the benefit of both developed and developing countries.

However, as Keynes himself pointed out, people hold to ideas long after they have been shown to be false. The Pacific island policies can be seen to be influenced still by the ideas of the long-defunct Bretton Woods system, with its in-built bias against trade and capital flows. The decision as to which of the two policy goals to follow should be made in the light of what is most important for the economic development of the country. As small, isolated countries, the Pacific's greatest need is to be able to exploit the economies of scale available from trade with the rest of the world. To do this they need to be open economies in order to take advantage of whatever technologies become available to overcome their inherent disadvantages. Unfortunately, their reluctance to open up to trade and investment only magnifies the disadvantages due to their smallness and isolation.

Those Pacific island countries with adjustable pegged currency regimes have elected to forgo open capital markets and to have exchange rate stability and monetary independence (Papua New Guinea with its 'managed' floating rate could even be included here). Therefore, if the Pacific small island states were to move to open capital markets in order to promote trade and investment, they must forego either the objective of exchange rate stability or of monetary independence. That is, they must either have a floating exchange rate or give up monetary independence. I suggest that their choice should be to adopt open capital markets and exchange rate stability and give up monetary independence.

\section{CONCLUSIONS}

The arguments put forward and the conclusion reached by de Brouwer (2000) in favour of Pacific island countries adopting the Australian dollar in place of their local currencies still seem to me to be justified. As de Brouwer makes clear, the optimal currency area conditions for a group of countries may be satisfied by a combination of the sharing of common external shocks, factor mobility, and factor price flexibility. Much of the subsequent published testing and arguments against the proposition do not appear to be relevant to the debate.

In re-examining the literature, I have discussed the factor mobility and factor price flexibility issues in more detail. I have also argued that circumstances 
affecting labour mobility, such as the aging of the global population, are changing in a positive direction for use of the Australian dollar as a common currency. Regional integration arrangements implemented as an outcome of the Pacific Plan could also increase factor mobility and factor price flexibility. Many of the indicators that have been found wanting in examinations of the case for use of a common currency are endogenous factors that will change significantly upon closer economic integration between the Pacific island countries and Australia and New Zealand. In this respect, there could be a larger role for fiscal transfers between Australia and New Zealand and Pacific states. As McKinnon (1963) points out, the capacity for fiscal transfers within the common currency bloc can be another means of compensating for differences in unemployment between the countries.

In Duncan (1994), I argue the case for those Pacific nations willing to do so to form a closer economic relationship with Australia and New Zealand. This relationship would involve a freer flow of labour and a common currency, as well as openness to trade and investment. However, the arrangement would have to be a formal contract involving commitments on the part of both parties. The Pacific states would have to commit to the sound and stable economic policies needed to place them on a higher economic growth path. For their part, Australia and New Zealand would provide assistance to the Pacific in the design and implementation of sound policies. As well, they should be ready to provide financial and material assistance to the Pacific nations in the event of shocks such as declines in commodity prices or natural disasters. The only way in which I would change the advice that I offered in 1994 would be to put much more emphasis on the need for more effective institutions in the Pacific and assistance from Australia and New Zealand in achieving this goal (such as secure property rights and impartial enforcement of contracts, with their underlying implications for the absence of discriminatory behaviour on the part of politicians, bureaucrats, and the courts). It seems to me that the explicit conditionality on Pacific island countries to adopt sound institutions and policies as the result of signing such a treaty would be much more effective than the conditionality attached to Australia's aid commitments.

There are, of course, the important questions of sequencing or prioritising in adopting such an integrated relationship. In the first place, Australia and New Zealand would have to agree on the framework of the economic relationship with the Pacific. If it were to be a joint effort, it would have to involve a 


\section{8

deepening of the economic relationship between the two countries, including with respect to labour mobility and currency arrangements. Should Australia and New Zealand agree to go ahead, should they negotiate with Pacific nations separately or as a bloc, or even instead of negotiation of the Pacific Agreement on Closer Economic Relations? Should there be a sequencing of the integration itself- of trade, investment, capital, labour, and currency arrangements? This is essentially the sequence followed by the European Union.

As far as sequencing is concerned, I would prefer to see improvements in property rights security and contract enforcement take place before going ahead with other reforms. Trade and investment liberalisation may have little pay-off in the absence of these basic institutions, although it is possible that trade and investment liberalisation could increase public demand for better institutions. As far as the other reforms are concerned, there seem to be good reasons for carrying out the integration simultaneously. In the case of the European Union, there were major gains to be realised from first opening up to trade, which created a favourable climate for the other reforms to follow. In the case of Pacific island countries, the transaction costs associated with using the illiquid local currencies may make the gains from trade liberalisation quite small. Therefore, the complementarity between simultaneously adopting a common currency such as the Australian dollar-with its associated openness to capital flows - and trade liberalisation could substantially increase the gains from trade. 